\title{
Employee Layoffs And Earnings Management
}

\author{
Steven C. Hall, (Email: hallsc@unk.edu), University of Nebraska, Kearney \\ William W. Stammerjohan, (Email: wstammer@cab.latech.edu), Louisiana Tech University \\ Gregory Cermignano, (Email: gregory.p.cermignano@widener.edu), Widener University
}

\begin{abstract}
This paper analyzes the accounting choices of firms in periods surrounding large work-force reductions (layoffs). Layoffs provide an incentive for managers to use accounting choices to manage earnings. Accrual analysis is performed on a sample of firms that announce large layoffs. Discretionary accruals are regressed on indicator variables for years associated with large layoffs. The results indicate that firms make accounting choices to reduce reported income in the years in which they announce large layoffs.
\end{abstract}

\section{INTRODUCTION}

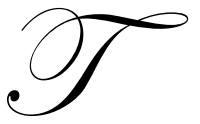

his paper analyzes accounting choices of firms in periods surrounding large workforce reductions (layoffs). Prior research finds that managers make accounting choices in predictable ways. Accounting choices are shown to be systematically affected by both firm contracts that are explicitly tied to accounting numbers, e.g., debt contract provisions and by situations only implicitly related to reported accounting numbers, e.g. political costs. ${ }^{1}$ Theories in the literature propose a general tendency to smooth earnings, and when earnings are too low to be smoothed, a tendency to understate earnings to enable future income smoothing. ${ }^{2}$

We argue that in periods of large layoffs managers have the incentive to use accounting choices to manage earnings. When the layoffs are a result of negative earnings that are large enough that firms are unable to report favorable results, managing accounting choices to reduce earnings in the current period clears the decks to allow favorable earnings reports in the future. In addition, the negative impact of layoffs on morale of remaining employees is dampened if the firm can demonstrate the need for layoffs (i.e., send the message that the company cares about the employees, but because of financial circumstances had no choice but to reduce the work force) and can report improved earnings subsequently to allay fears of further layoffs. Understanding the accounting behavior of firms surrounding large layoffs will help users better understand the financial statements of firms surrounding announcements of those layoffs.

Accrual analysis, similar to that of Jones (1991), and Cahan (1992) is performed on a sample of firms that announced large layoffs. Total accruals, and the components of total accruals, are regressed on two economic factors and an indicator variable for years associated with large layoffs using a two-way fixed effects covariance model that controls for both year and firm. Our findings indicate that firms reduce reported income with negative discretionary accruals in years in which they announce large layoffs.

The remainder of this study is organized as follows. The next section develops a relationship between work force reductions and accounting choices. The following sections describe the research design, the sample selection, the research methods, the results, the conclusions, and suggestions for future research. 


\section{WORK FORCE REDUCTION AND ACCOUNTING CHOICES}

This paper investigates the hypothesis that firms manage accruals to reduce earnings in periods surrounding significant corporate layoffs. Evidence indicates that firms smooth income to report favorable earnings from period to period. However, when poor performance precludes reporting favorable results, firms use accounting discretion to reduce earnings enabling smoothing to resume in future periods. Such behavior is predicted by two different hypotheses existing in the literature. ${ }^{3}$ The bonus plan hypothesis predicts that when earnings are below the lower bound of the bonus scheme managers will reduce income to save earnings for future periods when they can be used to increase management bonuses. The "big bath" hypothesis posits that firms reduce earnings in periods of poor performance to "clear the decks" for better earnings reports in future periods. Since large layoffs are normally associated with poor earnings performance, we expect firms announcing large layoffs to make income-decreasing accruals. This study is not intended as a test of either of the two hypotheses described above, nor is it intended as a test to differentiate between the hypotheses. It is intended as a descriptive study to better clarify accounting behavior during period of the significant event of layoffs.

Income-decreasing accruals may also have a positive effect on a firm's workforce since income-decreasing accruals in the current period results in income-increasing reversals in succeeding periods. Employees that remain with the firm suffer from downsizing. Among the various negative effects, downsizing causes anxiety prompting undesired employee turnover (Cameron et al. 1987) and decline-induced stress causing interpersonal and inter-unit conflicts (Whetten 1980). Workers who remain often experience feelings of depression, mistrust, betrayal, guilt, pain, loneliness, and job insecurity (Caudron 1996). There is also an increased tendency towards gossip (Wensky 1993) and fear of the future (Whigham-Desir 1993).

Decreasing reported earnings in the year of the layoff can alleviate much of the negative effect on remaining employees. Evidence from the literature in organizational justice indicates that employees are more likely to accept bad news if the reasons behind the decision are explained to them and the process seems fair. ${ }^{4}$ Making the layoffs seem more necessary than would premanaged earnings helps the layoffs seem fairer, alleviating feelings of mistrust and betrayal (Caudron 1996). The reversal of the accruals in future periods, increases income in those periods making workers feel more secure and alleviating anxiety and fear of the future. ${ }^{5}$

On the other hand, manipulating accruals to report lower earnings may be costly to the firm in that lower earnings may decrease the share price. Research indicates that layoff announcements are generally preceded by a period of poor earnings performance, are accompanied by a negative stock price reaction, and followed by improved earnings and price performance (e.g., Chen et al. 2001). Given that both the poor prior earnings performance and the layoff announcement provide negative signals to the stock market, we suspect the marginal impact on stock prices of downward accrual manipulation to be small.

\section{RESEARCH DESIGN}

Dechow et al. (1995) evaluate the ability of alternative accrual models to detect earnings management. They conclude that a modified version of the model developed by Jones (1991) provides the most powerful test of earnings management. We use a form of the modified Jones model to measure discretionary accruals in this study. The model regresses total accruals on the change in sales and the fixed asset balance. The modified Jones model includes a control for the potential manipulation of sales revenue in the test period. The modified Jones model uses the change in reported sales revenue, $\triangle$ SALES, less any change in accounts receivable as the explanatory variable in periods theorized to include manipulation (Dechow et al. 1995). ${ }^{6}$ The portion of total accruals not explained by this set of explanatory variables is our estimate of discretionary accruals. The basic accrual model is:

$$
A_{i t}=b_{0}+b_{1} \triangle S A L E S_{i t}+b_{2} F A_{i t}+e_{i t}
$$


where:

A $\quad=$ total accruals (deflated by lagged total assets) for firm $\mathrm{i}$ in year $\mathrm{t}$,

$\triangle$ SALES $_{\text {it }} \quad=$ change in sales (deflated by lagged total assets) for firm $\mathrm{i}$ from year $\mathrm{t}-1$ to year $\mathrm{t}$, during non-event periods (periods in which earnings management is not hypothesized), and change in sales for firm $\mathrm{i}$ from year $\mathrm{t}-1$ to year $\mathrm{t}$ less the change in receivables balance for firm $\mathrm{i}$ from year t-1 to year $\mathrm{t}$ (all deflated by total assets) during event periods (periods in which earnings management is hypothesized); and

$\mathrm{FA}_{\mathrm{it}} \quad=$ balance of fixed assets (deflated by lagged total assets) at the end of year $\mathrm{t}$ for firm $\mathrm{i}$.

To test for accrual manipulation, we expand model (1) to include indicator variables to detect the effect of announcements of large layoffs on discretionary accruals.

Dechow et al. (1995) also demonstrate that for firms with extremely poor performance, discretionary accruals, as measured by the Jones model, are significantly negative without considering any specific stimulus. Since the event of large layoffs is reasonably expected to be correlated with poor earnings performance, the results of our tests using the Jones model are biased in favor of rejecting the null hypothesis of no accrual management. We control for this effect by including an earnings performance measure in the regression, as recommended by Dechow et al (1995).

\section{DATA AND METHODS}

\section{Sample}

We searched the Wall Street Journal Index for the twenty-year period 1976-1995 for reports of firms that had lain off a significant number of employees. ${ }^{7}$ To be considered for the sample, we required that the firm have a minimum of eight years of data available on Compustat, that those years encompass the year of the layoff announcement, and that the announced layoff represent a minimum of one percent of the firm's workforce. ${ }^{\mathbf{8}}$ We also required, for each firm, that the first announced layoff in the test period be preceded by two years in which no layoffs were announced. These procedures yielded 518 announcements affecting 367 firms. Data are pooled yielding a final sample 6,303 firm-years. Table 1 reports layoff events by year.

\section{Method}

We use three alternative measures of total accruals, a traditional individual components measure of accruals, hereinafter components accruals, and two measures based on the difference between operating cash flows and earnings, hereinafter cash-flow accruals. Total accruals using the components approach is calculated for each firm year as follows:

$$
A_{i t}=\frac{-D E P_{i t}+\left(\Delta A R_{i t}\right)+\left(\Delta I N V_{i t}\right)-\left(\Delta A P_{i t}\right)-\left(\Delta T P_{i t}\right)-D T_{i t}}{T A_{i t-1}}
$$

where

$$
\begin{aligned}
& \mathrm{DEP}_{\text {it }} \quad=\quad \text { depreciation expense for firm } \mathrm{i} \text { in year } \mathrm{t} \text {; } \\
& \Delta \mathrm{AR}_{\mathrm{it}}=\quad \text { the change in accounts receivable balance from year } \mathrm{t}-1 \text { to year } \mathrm{t} \text { for firm } \mathrm{i} \text {; } \\
& \Delta \mathrm{INV}_{\mathrm{it}}=\quad \text { the change in inventory balance from year } \mathrm{t}-1 \text { to year } \mathrm{t} \text { for firm } \mathrm{i} \text {; } \\
& \Delta \mathrm{AP}_{\mathrm{it}}=\quad \text { the change in accounts payable balance from year } \mathrm{t}-1 \text { to year } \mathrm{t} \text { for firm } \mathrm{i} \text {; } \\
& \Delta \mathrm{TP}_{\mathrm{it}}=\text { the change in taxes payable balance from year } \mathrm{t}-1 \text { to year } \mathrm{t} \text { for firm } \mathrm{i} \text {; } \\
& \mathrm{DT}_{\text {it }}=\text { deferred tax expense for firm } \mathrm{i} \text { in year } \mathrm{t} \text {; and } \\
& \mathrm{TA}_{\mathrm{it}}=\text { total asset balance for firm } \mathrm{i} \text { at the end of year } \mathrm{t} \text {. }
\end{aligned}
$$


Total accruals using the cash-flow approach is calculated as either:

$$
A_{i t}=\frac{I B_{i t}-O C F_{i t}}{T A_{i t-1}}
$$

or

$$
A_{i t}=\frac{N I_{i t}-O C F_{i t}}{T A_{i t-1}}
$$

where

$$
\begin{array}{lll}
\mathrm{IB}_{\text {it }} & = & \text { Income before discontinued operations and extraordinary items for firm } \mathrm{i} \text { in year } \mathrm{t} \\
\mathrm{NI}_{\mathrm{it}} & =\text { net income for firm } \mathrm{i} \text { in year } \mathrm{t} ; \text { and } \\
\mathrm{OCF}_{\text {it }} & =\text { operating cash flow for firm } \mathrm{i} \text { in year } \mathrm{t} .
\end{array}
$$

Table 1: Descriptive Statistics

\begin{tabular}{ccccc}
\hline Year & $\begin{array}{c}\text { Total Number of Firms } \\
\text { in Sample }\end{array}$ & $\begin{array}{c}\text { Number of Firms } \\
\text { Announcing Layoffs }\end{array}$ & $\begin{array}{c}\text { Average Total Assets of } \\
\text { Layoff Firms }\end{array}$ \\
\hline 1977 & 286 & 28 & 3,757 & 1,902 \\
1978 & 287 & 16 & 4,248 & 1,610 \\
1979 & 289 & 2 & 4,881 & 21,623 \\
1980 & 290 & 2 & 5,446 & 4,952 \\
1981 & 293 & 5 & 5,946 & 2,123 \\
1982 & 293 & 16 & 6,681 & 2,304 \\
1983 & 319 & 6 & 7,043 & 4,288 \\
1984 & 334 & 2 & 7,142 & 42,837 \\
1985 & 344 & 0 & 8,246 & 14,472 \\
1986 & 353 & 4 & 8,881 & $-1,43$ \\
1987 & 362 & 0 & 9,939 & 85,113 \\
1988 & 368 & 2 & 11,016 & 50,394 \\
1989 & 366 & 5 & 12,151 & 19,956 \\
1990 & 366 & 57 & 13,082 & 20,534 \\
1991 & 364 & 88 & 13,827 & 14,896 \\
1992 & 365 & 98 & 14,398 & 15,168 \\
1993 & 362 & 92 & 15,209 & 15,464 \\
1994 & 358 & 95 & 16,455 & - \\
1995 & 304 & 0 & 19,613 & \\
Firm/yrs & 6,303 & 518 & &
\end{tabular}

Average Total Assets - Average totals assts for all sample firms for that sample year.

Average Total Assts of Layoff Firms - Average totals assts for layoff firms for that sample year.

Both the components and cash flow measures of accruals have important advantages and taken together present a more complete picture of accrual behavior than either can do taken alone. Hibrar and Collins (2002) document that the components measure of accruals should not be used for firms engaged in merger activity, with significant discontinued operations, or with significant foreign currency translations. Firms with significant discontinued operations or write-offs in the event year, as firms with large layoffs are likely to have, measure accruals for the entire firm in the prior year and accruals of a reduced firm in the event year, producing biased results. The cash flow measure of accruals avoids this bias. 
On the other hand, using the cash-flow measure has important weaknesses. In focusing on management of accruals surrounding large layoffs, we are interested in the hidden accruals in normal accounts. The cash-flow measure of accruals includes all differences between earnings and cash flow from operations and thus those explicitly reported non-recurring charges (e.g., severance costs), write-downs, and restructuring charges associated with large layoffs. While these non-recurring charges may represent legitimate abnormal accruals taken in the normal course of a layoff, we posit that accruals in normal business accounts that are unexplained by model (1) during the layoff periods more accurately represent accrual manipulation.

The SFAS 95 cash flow from operations information required to calculate total accruals using the cash flow approach is available for only the last eight years of our sample period. Using this measure eliminates approximately half of our sample firm/years. Retaining sufficient sample size to run the model on smaller subsets of data would require relaxing the requirement of having eight years of data for each firm in the model. Decreasing the number of years decreases the stability of the model.

Using the components measure of total accruals allows us to better focus on hidden accruals, estimate with larger sample sizes and with more estimation years per firm. Furthermore, using the components measure allows us to examine the individual components of accruals to determine which of those accounts is actually being managed and come to a better understanding of the detailed nature of accrual manipulation surrounding large layoffs. The problem of bias due to mergers, significant discontinued operations, foreign currency translations, and one-time write-offs is controlled by eliminating firms that report these items. Thus, our tests are conducted on four different samples. The Full Sample includes all sample firms. The Clean Sample excludes all firms reporting mergers, discontinued operations, and foreign currency transactions in the event period. The Clean NSPI sample excludes both the firms reporting mergers, discontinued operations, and foreign currency transactions and firms reporting special items (as defined by Compustat) during the event period. The Cash Flow sample includes only those firms for which operating cash flow information was available. Table 2 contains descriptive information for each of the four samples.

Model (1) is expanded to include variables to test the effect of announcements of large work force reductions on discretionary accruals. LAYOFF is a dichotomous variable set equal to one for years in which the firm announced large layoffs and zero in other years. We expect that in years when LAYOFF is equal to one, firms will make incomedecreasing discretionary accruals. If firms plan and anticipate layoffs, accrual manipulation may begin in the period prior to the announcement. LAYOFFM1 is a dichotomous variable set equal to one in the year immediately prior to the year of an announcement of large layoffs provided there was no additional announcement in the two preceding years. ${ }^{9}$ LOSS is a dichotomous variable set equal to one in the years in which the firm reported a loss and zero in other years. LOSS is included to control for the negative accrual bias of firms reporting extreme poor earnings performance as documented by Dechow et al. (1995). The effect of large layoff announcements is tested by estimating model (5):

$$
A_{i t}=b_{i t 0}+b_{1} \Delta S A L E S_{i t}+b_{2} F A_{i t}+b_{3} L A Y O F F_{i t}+b_{4} \text { LAYOFFM }_{i t}+b_{5} \text { LOSS }_{i t}+e_{i t}
$$

where:

$\mathrm{A}_{\mathrm{it}}, \triangle \mathrm{SALES} \mathrm{St}_{\mathrm{it}}$, and $\mathrm{FA}_{\mathrm{it}}$ are defined as above,

$\mathrm{LAYOFF}_{\text {it }} \quad=1$ in year firm $\mathrm{i}$ announced layoffs, 0 otherwise,

LAYOFFM $1_{\text {it }} \quad=1$ in year prior to announcement of layoffs by firm i, 0 otherwise, and

LOSS $_{\text {it }} \quad=1$ in year firm i reported net loss, 0 otherwise.

The expected sign of the $\triangle$ SALES coefficient is positive. The expected signs for the FA, LAYOFF, LAYOFFM1, and LOSS are all negative. Model (5) is estimated using the fixed effects covariance model described by Pindyck and Rubinfeld (1981, 254-255) and used by Cahan (1992). The fixed effects estimation results in a firm/year specific intercept, $b_{0 i t}$. 
Table 2: Descriptive Statistics by Sample

\begin{tabular}{|c|c|c|c|c|c|c|c|}
\hline \multirow[b]{2}{*}{ Sample } & \multirow[b]{2}{*}{ \# of firms } & \multirow[b]{2}{*}{ \# of jobs. } & \multicolumn{2}{|c|}{ \# of observations per firm } & \multirow{2}{*}{$\begin{array}{c}\text { Percent } \\
\text { event year } \\
\text { observations }\end{array}$} & \multicolumn{2}{|c|}{$\begin{array}{l}\text { Total Assets } \\
\text { (\$ millions) }\end{array}$} \\
\hline & & & Mean & Median & & Mean & Median \\
\hline Full & 367 & 6,303 & 17 & 19 & 8.2 & 10,150 & 2,032 \\
\hline Clean & 195 & 2,732 & 14 & 14 & 8.6 & 7,661 & 1,530 \\
\hline Clean NSPI & 108 & 1,344 & 12 & 12 & 5.4 & 8,486 & 1,710 \\
\hline Cash Flow & 327 & 2,517 & 8 & 8 & 15.9 & 10,018 & 2,368 \\
\hline \multirow[t]{2}{*}{ Sample } & \multicolumn{2}{|c|}{$\begin{array}{c}\text { Total Sales Revenue } \\
(\$ \text { millions })\end{array}$} & \multicolumn{3}{|c|}{$\begin{array}{c}\text { Total Accruals-components } \\
(\$ \text { millions })\end{array}$} & \multicolumn{2}{|c|}{$\begin{array}{l}\text { Net Income } \\
\text { (\$ millions) }\end{array}$} \\
\hline & Mean & Median & & & Median & Mean & Median \\
\hline Full & 5,812 & 1,891 & & & $(41)$ & 237 & 63 \\
\hline Clean & 4,173 & 1,371 & & & (35) & 187 & 48 \\
\hline Clean NSPI & 4,136 & 1,375 & & & (23) & 248 & 70 \\
\hline Cash Flow & 7,354 & 2,147 & & & $(57)$ & 246 & 56 \\
\hline \multirow[t]{2}{*}{ Sample } & \multicolumn{2}{|c|}{$\begin{array}{l}\text { Income From Continuing } \\
\text { Operations ( } \$ \text { millions) }\end{array}$} & \multicolumn{3}{|c|}{ Deflated Net Income* } & \multicolumn{2}{|c|}{$\begin{array}{l}\text { Deflated Income from Continuing } \\
\text { Operations }\end{array}$} \\
\hline & Mean & Median & & & Median & Mean & Median \\
\hline Full & 253 & 65 & & & 0.0445 & 0.0311 & 0.0443 \\
\hline Clean & 202 & 49 & & & 0.0444 & 0.0274 & 0.0443 \\
\hline Clean NSPI & 258 & 72 & & & 0.0503 & 0.0510 & 0.0499 \\
\hline Cash Flow & 288 & 66 & & & 0.0353 & 0.0147 & 0.0364 \\
\hline \multirow[t]{2}{*}{ Sample } & \multicolumn{2}{|c|}{$\begin{array}{l}\text { Deflated Total Accruals (based on } \\
\text { the total accruals as defined by } \\
\text { model (2) }\end{array}$} & \multicolumn{3}{|c|}{$\begin{array}{c}\text { Deflated Total Accruals (based on } \\
\text { net income less operating cash } \\
\text { flows) }\end{array}$} & \multicolumn{2}{|c|}{$\begin{array}{c}\text { Deflated Total Accruals (based on } \\
\text { income from continuing } \\
\text { operations less operating cash } \\
\text { flows) }\end{array}$} \\
\hline & Mean & Median & & & Median & Mean & Median \\
\hline Full & -0.0348 & -0.0373 & & & & & \\
\hline Clean & -0.0345 & -0.0387 & & & & & \\
\hline Clean NSPI & -0.0227 & -0.0288 & & & & & \\
\hline Cash Flow & -0.0440 & -0.0437 & & & -0.0558 & -0.0667 & -0.0563 \\
\hline
\end{tabular}

* All deflated variables are deflated by total assets.

Samples: Full - Full pooled sample over all available years for the 367 sample firms.

Clean - Full pooled sample less firm years that include mergers, discontinued operations, and/or foreign currency translations.

Clean NSPI - Clean sample less firm years that include special income items.

Cash Flow - Full sample firm years that include SFAS 95 operating cash flow information.

\section{TESTS AND RESULTS}

Results column (1) of Table 3 reports the results of the fixed effects covariance estimation of model (5) on our full sample using the components measure of total accruals. Both $\triangle$ SALES and FA are statistically significant as predicted. The F statistic for the model is significant at the 0.0001 level. $\mathrm{R}^{2}$ is 41 percent. These results are similar to those of prior studies and support the notion that the change in sales and the level of fixed assets explain a significant portion of total accruals. ${ }^{10}$ LAYOFF is significant at the 0.02 level when the LOSS variable is not included and at 0.07 when it is included, indicating that firms take steps to reduce income through the use of discretionary accruals in years of large-layoff announcements. The LAYOFF coefficient of -0.0083 indicates that, on average, discretionary accruals reduced reported income by $0.83 \%$ of total assets in the layoff announcement years. This amount corresponds to a $36.1 \%$ understatement of average return on assets or an $\$ 84$ million dollar understatement of income by an average size firm. ${ }^{11}$ LAYOFFM1 is not statistically significant. There is no indication from these results that firms manage earnings in the year prior to the year of layoff announcement. 
Table 3: Model (3) Regression Results/Full Sample and Cash Flow Sample

\begin{tabular}{|c|c|c|c|c|c|c|c|c|c|}
\hline \multicolumn{10}{|c|}{$A_{i t}=b_{0 i t}$} \\
\hline \multicolumn{2}{|c|}{ Results Columns } & \multicolumn{2}{|c|}{ (1) } & \multicolumn{2}{|c|}{ (2) } & \multicolumn{2}{|c|}{ (3) } & \multicolumn{2}{|c|}{ (4) } \\
\hline $\begin{array}{l}\text { Accrual } \\
\text { Measure }\end{array}$ & & \multicolumn{2}{|c|}{ Components } & \multicolumn{2}{|c|}{ Components } & \multicolumn{2}{|c|}{$\mathrm{ACO}$} & \multicolumn{2}{|c|}{ ANI } \\
\hline \multicolumn{2}{|l|}{ Sample } & \multicolumn{2}{|c|}{ Full } & \multicolumn{2}{|c|}{ Cash Flow } & \multicolumn{2}{|c|}{ Cash Flow } & \multicolumn{2}{|c|}{ Cash Flow } \\
\hline $\begin{array}{c}\text { Independ. } \\
\text { Variable }\end{array}$ & $\begin{array}{c}\text { Expected } \\
\text { Sign } \\
\end{array}$ & $\begin{array}{l}\text { Estimate } \\
t \text {-statistic } \\
\text { one-tailed p }\end{array}$ & obability & & & & & & \\
\hline \multirow[t]{3}{*}{ Intercept } & & -0.0859 & -0.0849 & -0.2129 & -0.2098 & 0.8395 & 0.8514 & 0.7522 & 0.7641 \\
\hline & & -0.9800 & -0.9700 & -0.6200 & -0.6200 & 2.0700 & 2.2000 & 1.4200 & 1.4800 \\
\hline & & 0.1870 & 0.1664 & 0.2671 & 0.2693 & 0.0194 & 0.0141 & 0.0784 & 0.0699 \\
\hline \multirow[t]{3}{*}{$\triangle$ SALES } & + & 0.1573 & 0.1507 & 0.1693 & 0.1614 & 0.1362 & 0.1061 & 0.1535 & 0.1235 \\
\hline & & 31.6100 & 29.6300 & 20.4800 & 19.1500 & 13.9000 & 11.0800 & 11.9800 & 9.6700 \\
\hline & & 0.0001 & 0.0001 & 0.0001 & 0.0001 & 0.0001 & 0.0001 & 0.0001 & 0.0001 \\
\hline \multirow[t]{3}{*}{ FA } & - & -0.1308 & -0.1280 & -0.1155 & -0.1062 & -0.1306 & -0.0953 & -0.1668 & -0.1316 \\
\hline & & -10.0900 & -9.9000 & -4.1500 & -3.8200 & -3.9600 & -3.0200 & -3.8600 & -3.1200 \\
\hline & & 0.0001 & 0.0001 & 0.0001 & 0.0001 & 0.0001 & 0.0013 & 0.0001 & 0.0009 \\
\hline \multirow[t]{3}{*}{ LAYOFF } & - & -0.0083 & -0.0060 & -0.0097 & -0.0065 & -0.0261 & -0.0141 & -0.2309 & -0.0111 \\
\hline & & -2.0300 & -1.4500 & -1.9200 & -1.2800 & -4.3500 & -2.4200 & -2.9400 & -1.4300 \\
\hline & & 0.0214 & 0.0735 & 0.0113 & 0.1000 & 0.0001 & 0.0078 & 0.0017 & 0.0760 \\
\hline \multirow[t]{3}{*}{ LAYOFFM1 } & - & 0.0007 & 0.0028 & -0.0019 & 0.0008 & -0.0134 & -0.0030 & -0.0189 & -0.0086 \\
\hline & & 0.1500 & 0.6000 & -0.3500 & 0.1500 & -2.0600 & -0.4900 & -2.2300 & -1.0300 \\
\hline & & 0.5610 & 0.7256 & 0.3632 & 0.5581 & 0.0196 & 0.3128 & 0.0130 & 0.1510 \\
\hline \multirow[t]{3}{*}{ LOSS } & - & & -0.0197 & & -0.0217 & & -0.0826 & & -0.0822 \\
\hline & & & -5.8400 & & -4.3500 & & -14.5900 & & -10.8800 \\
\hline & & & 0.0001 & & 0.0001 & & 0.0001 & & 0.0001 \\
\hline $\mathrm{N}$ & & 6,303 & 6,303 & 2,517 & 2,517 & 2,517 & 2,517 & 2,517 & 2,517 \\
\hline $\mathrm{R}^{2}$ & & 0.4148 & 0.4181 & 0.5184 & 0.5226 & 0.5377 & 0.5788 & 0.4042 & 0.4349 \\
\hline Adjusted $\mathrm{R}^{2}$ & & 0.3740 & 0.3775 & 0.4440 & 0.4485 & 0.4663 & 0.5135 & 0.3221 & 0.3473 \\
\hline $\mathrm{F}$ & & 10.1900 & 10.3000 & 6.9600 & 7.0600 & 7.5200 & 8.8600 & 4.3900 & 4.9600 \\
\hline Prob. F & & 0.0001 & 0.0001 & 0.0001 & 0.0001 & 0.0001 & 0.0001 & 0.0001 & 0.0001 \\
\hline $\mathrm{A}^{*}$ & - Total accr & ual measure. & & & & & & & \\
\hline Components & - Total accr & uals as define & by model & & & & & & \\
\hline $\mathrm{ACO}$ & $\begin{array}{r}\text { - Total accr } \\
\text { less oper }\end{array}$ & $\begin{array}{l}\text { uals equal to } \\
\text { rating cash fl }\end{array}$ & $\begin{array}{l}\text { arnings bef } \\
\text { ws. }\end{array}$ & re extraorc & ary items a & discontin & operation & & \\
\hline ANI & - Total accr & uals equal to & et income 1 & ss operatir & cash flows & & & & \\
\hline$\triangle$ SALES & - Change in & sales. & & & & & & & \\
\hline FA & - Fixed asse & & & & & & & & \\
\hline LAYOFF & - Equal to o & ne if layoff y & ar, zero oth & rwise. & & & & & \\
\hline $\begin{array}{l}\text { LAYOFFM1 } \\
\text { LOSS }\end{array}$ & $\begin{array}{l}\text { - Equal to o } \\
\text { - Equal to } \\
\text { otherwise. }\end{array}$ & $\begin{array}{l}\text { one if year bef } \\
\text { one if earn }\end{array}$ & $\begin{array}{l}\text { re layoff ye } \\
\text { igs before }\end{array}$ & $\begin{array}{l}\text { r, zero oth } \\
\text { xtraordina }\end{array}$ & $\begin{array}{l}\text { wise. } \\
\text { items an }\end{array}$ & discontint & operatio & less th & zero, zero \\
\hline
\end{tabular}


Columns (3) and (4) of Table 3 present the results of tests using the cash flow measure of total accruals. Notice that the sample size is reduced by more than one-half when firm-years without cash-flow information are deleted from the sample. Column (2) reports results of using the components measure with the reduced sample for comparison purposes. $\triangle$ SALES and FA remain significant as predicted. Results for LAYOFFS is notably stronger in columns (3) and (4) than in columns (1) and (2). We believe this is because of the inclusion of those explicitly reported nonrecurring charges that are not contained in one of the six components of total accruals, as was noted above.

Hibrar and Collins (2002) document that the components measure of accruals is inappropriate for firms engaged in mergers, for firms with significant discontinued operations, and for firms with significant foreign currency translations. This concern is addressed in the clean sample results reported in column (1) of Table 4. The clean sample does not include any firm years that included merger activities or any firm years that had either significant discontinued operations or foreign currency translations, using the Hibrar and Collins (2002) cutoffs. ${ }^{12}$ The results are similar to those in Table 3.

The additional concern that the results reflect one-time write-offs in the layoff years is addressed in column (2) of Table 4 by removing all firm years that included special items as defined by Compustat item SPI. This reduced sample is referred to as our clean NSPI sample. Results are similar to those reported in Table 3.

To better visualize the effect of layoff events, we exclude LAYOFF and LAYOFFM1 from the components accrual version of model (5) and calculate the residuals in the following model:

$$
A_{i t}=b_{0}+b_{1} \Delta S A L E S_{i t}+b_{2} F A_{i t}+b_{3} L O S S_{i t}+e_{i t}
$$

Net income is scaled by total assets and adjusted using these residuals to get an estimate of deflated pre-managed income. Then, these deflated measures of net income and pre-managed income are plotted with respect to event years in Figure 1. Figure 1 includes the averages for three years prior to the first layoff year, and for three years after the last layoff year. Panel A represents results using the full sample of 6,303 firm-years, and panel B represents results using the clean NSPI sample of 1,344 firm-years. The first layoff year is the year of a layoff preceded by at least two years with no layoff announcements. The last layoff year is the year of a layoff immediately succeeded by two years with no layoff announcements. (The first and last layoff years are often the same year.) There is a marked decline in discretionary accruals in the first layoff year in both samples and a marked increase in year +2 in the full sample and year +3 in the clean NSPI sample.

To better understand the nature of accrual management in periods surrounding the event of large layoffs we estimate our model using the individual components of accruals as the dependent variable. Hall and Stammerjohan (1997) found markedly different results estimating working-capital versus nonworking-capital accruals. Table 5 reports results of the fixed effects covariance estimations of model (5) with the six individual components of accruals alternately used as the dependent variable. The estimations are run on the full and clean NSPI samples. If reported income is reduced through the manipulation of accruals in normal business accounts, such as current asset and liability accounts, we would expect LAYOFFS to be a significant predictor of the reported changes unexplained by model (1) in the layoff announcement periods.

Estimations reported in Table 5 indicate that five of the six components models are estimated with overall significance at the 0.0001 level. Only the $\Delta \mathrm{TP}$ model failed to be significant at conventional levels. The adjusted $\mathrm{R}^{2} \mathrm{~s}$ on the significant models ranged from 0.13 to 0.93 . As would be expected, $\triangle$ SALES was a significant predictor of changes in both current assets and current liabilities. Increases in sales correspond to both larger debit balances in accounts receivable and inventory and larger credit balances in accounts payable. Also, as expected, the level of fixed assets is a significant predictor of depreciation expense. 
Table 4: Model (3) Regression Results/Clean and Clean NSPI Samples

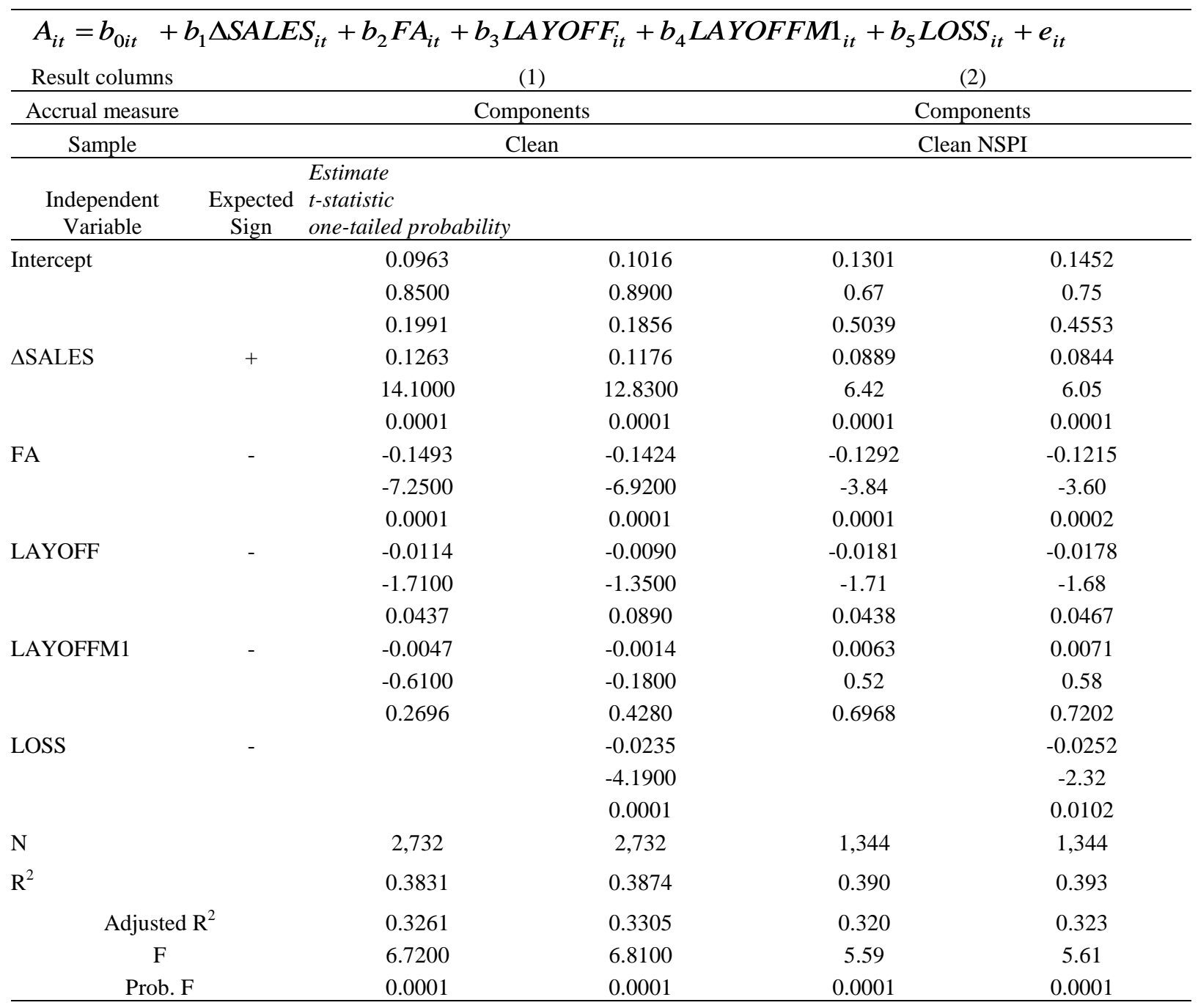

A* - Total accruals measure.

Components - Total accruals as defined by model (2).

$\triangle$ SALES - Change in sales.

FA - Fixed assets.

LAYOFF - Equal to one if layoff year, zero otherwise.

LAYOFFM1 - Equal to one if year before layoff year, zero otherwise.

LOSS - Equal to one if earnings before extraordinary items and discontinued operations is less than zero, zero otherwise.

*All variables are deflated by total assets. 
Figure 1 - Panel A: Full Sample

Income and Discretionary Accruals
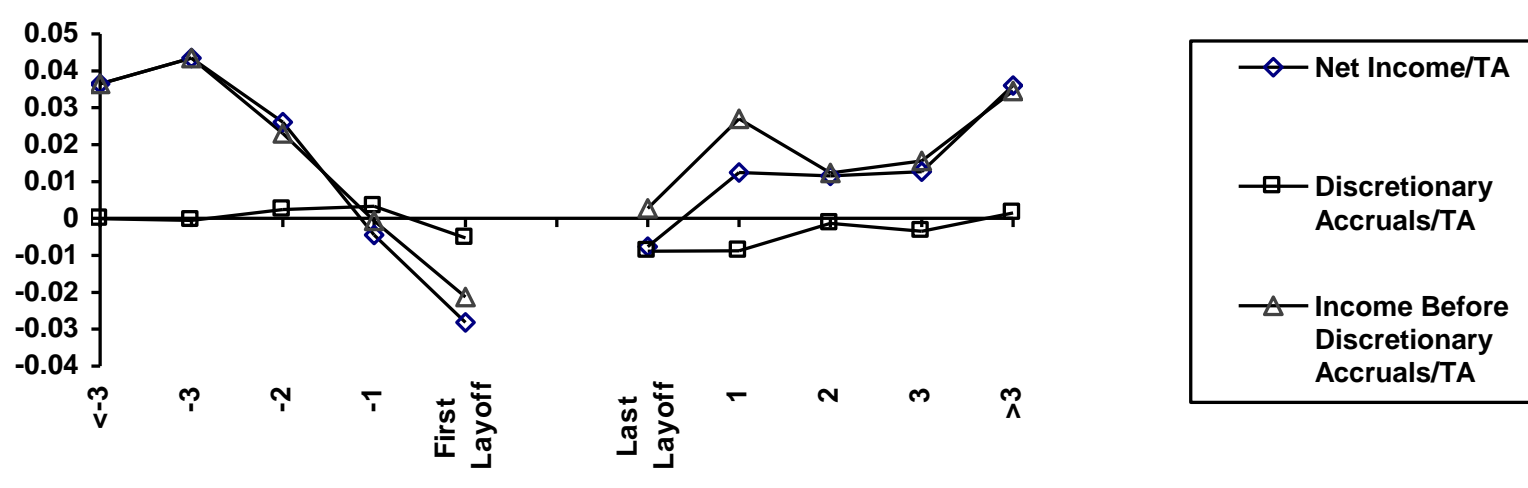

Figure 1 - Panel B: Clean NSPI Sample Income and Discretionary Accruals
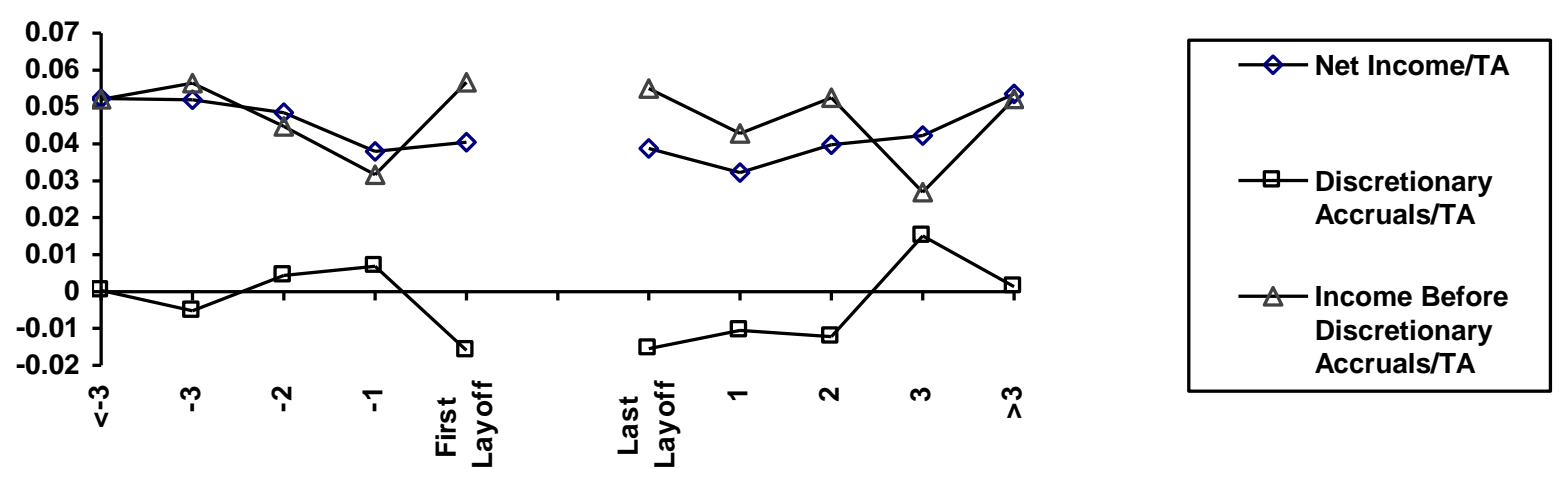

The LAYOFF coefficient is significant and in the predicted direction in several of the estimations. LAYOFF is significant $(\mathrm{p} \leq 0.0377)$ in the $\triangle \mathrm{AR}$ model in the clean/no special items sample. ${ }^{13}$ Accounts receivable are decreased more than can be explained by the change in sales and by negative earnings performance, indicating that firms may delay the reporting of revenue to decrease earnings. LAYOFF is significant $(\mathrm{p} \leq 0.0007)$ in the $\Delta \mathrm{INV}$ model for all estimations, indicating that inventory levels are lower in layoff years than can be explained by change in sales and negative earnings performance. However, we would expect layoffs to be associated with excess inventories, so this effect might be expected in the absence of any earnings manipulation as firms reduce excess inventories. Thus, these results alone are not conclusive, but when taken together with the other results, they are consistent with accrual manipulation. 
Table 5 - Panel A: Model (4) Regression Results/Full and Clean NSPI Samples

\begin{tabular}{|c|c|c|c|c|c|c|c|c|c|c|}
\hline$A C O M P_{i t}$ & $=b_{0 i t}$ & $+b_{1} \Delta S A$ & $E S_{i t}+$ & $F A_{i t}+$ & $A Y O F$ & $i t+b$ & $A Y O F$ & $1_{i t}+b$ & $O S S_{i t}+$ & \\
\hline $\begin{array}{l}\text { Dependent } \\
\text { Variable }\end{array}$ & & & $\triangle \mathrm{AR}$ & & & & & $\Delta \mathrm{INV}$ & & \\
\hline Sample & & & & Clea & NSPI & & & & Clea & JSPI \\
\hline $\begin{array}{l}\text { Independent } \\
\text { Variable } \\
\end{array}$ & $\begin{array}{l}\text { Exp. } \\
\text { Sign }\end{array}$ & & & & & $\begin{array}{l}\text { Exp. } \\
\text { Sign }\end{array}$ & & & & \\
\hline Intercept & & -0.0632 & -0.0623 & 0.1299 & 0.1381 & & -0.0735 & -0.0729 & -0.1545 & -0.1437 \\
\hline & & -0.99 & -0.98 & 1.08 & 1.15 & & -1.50 & -1.49 & -1.51 & -1.41 \\
\hline & & 0.3229 & 0.3276 & 0.2817 & 0.2522 & & 0.1339 & 0.1357 & 0.1318 & 0.1597 \\
\hline$\triangle$ SALES & + & 0.1150 & 0.1088 & 0.0789 & 0.0765 & + & 0.1111 & 0.1076 & 0.0534 & 0.0502 \\
\hline & & 31.79 & 29.49 & 9.20 & 8.84 & & 40.08 & 37.96 & 7.33 & 6.85 \\
\hline & & 0.0001 & 0.0001 & 0.0001 & 0.0001 & & 0.0001 & 0.0001 & 0.0001 & 0.0001 \\
\hline FA & $?$ & -0.0406 & -0.0380 & -0.0433 & -0.0391 & $?$ & -0.0111 & -0.0096 & -0.0264 & -0.0209 \\
\hline & & -4.31 & -4.05 & -2.08 & -1.87 & & -1.53 & -1.33 & -1.49 & -1.18 \\
\hline & & 0.0001 & 0.0001 & 0.0380 & 0.0617 & & 0.1254 & 0.1832 & 0.1360 & 0.2383 \\
\hline LAYOFF & - & -0.0046 & -0.0025 & -0.0119 & -0.0117 & - & -0.0086 & -0.0073 & -0.0192 & -0.0190 \\
\hline & & -1.55 & -0.82 & -1.81 & -1.78 & & -3.75 & -3.20 & -3.45 & -3.41 \\
\hline & & 0.0601 & 0.2066 & 0.0355 & 0.0377 & & 0.0001 & 0.0007 & 0.0003 & 0.0004 \\
\hline LAYOFFM1 & - & -0.0005 & 0.0014 & -0.0098 & -0.0093 & - & 0.0024 & 0.0035 & 0.0077 & 0.0083 \\
\hline & & -0.15 & 0.42 & -1.29 & -1.23 & & 0.91 & 1.34 & 1.20 & 1.30 \\
\hline & & 0.4403 & 0.6640 & 0.0986 & 0.1090 & & 0.8183 & 0.9093 & 0.8847 & 0.9023 \\
\hline LOSS & - & & -0.0184 & & -0.0136 & - & & -0.0106 & & -0.0181 \\
\hline & & & -7.51 & & -2.03 & & & -5.60 & & -3.17 \\
\hline & & & 0.0001 & & 0.0215 & & & 0.0001 & & 0.0008 \\
\hline$N$ & & 6,303 & 6,303 & 1,344 & 1,344 & & 6.303 & 6,303 & 1,344 & 1,344 \\
\hline $\mathrm{R}^{2}$ & & 0.345 & 0.351 & 0.445 & 0.447 & & 0.349 & 0.353 & 0.393 & 0.398 \\
\hline Adjusted R & & 0.300 & 0.306 & 0.381 & 0.383 & & 0.304 & 0.307 & 0.323 & 0.328 \\
\hline $\mathrm{F}$ & & 7.58 & 7.77 & 7.00 & 7.00 & & 7.71 & 7.81 & 5.65 & 5.72 \\
\hline Prob. F & & 0.0001 & 0.0001 & 0.0001 & 0.0001 & & 0.0001 & 0.0001 & 0.0001 & 0.0001 \\
\hline ACOMP* & - Comp & nent of tot & accruals. & & & & & & & \\
\hline$\Delta \mathrm{AR}$ & - Chang & in accoun & receivab & & & & & & & \\
\hline$\Delta \mathrm{INV}$ & - Chang & in invent & & & & & & & & \\
\hline$\triangle$ SALES & - Chang & in sales. & & & & & & & & \\
\hline FA & - Fixed & ssets. & & & & & & & & \\
\hline LAYOFF & - Equal & o one if la & ff year, $\mathrm{z}$ & otherwi & & & & & & \\
\hline $\begin{array}{l}\text { LAYOFFM1 } \\
\text { LOSS }\end{array}$ & $\begin{array}{l}\text { - Equal } \\
\text { - Equal } \\
\text { otherwi }\end{array}$ & $\begin{array}{l}\text { o one if ye } \\
\text { to one if } \\
\text { e. }\end{array}$ & $\begin{array}{l}\text { before la } \\
\text { arnings } b\end{array}$ & $\begin{array}{l}\text { ff year, } z \\
\text { ore extra }\end{array}$ & $\begin{array}{l}\text { otherwis } \\
\text { inary ite }\end{array}$ & e. & scontinu & operation & is less th & zero, zero \\
\hline
\end{tabular}


Table 5 - Panel B: Model (4) Regression Results/Full and Clean NSPI Samples

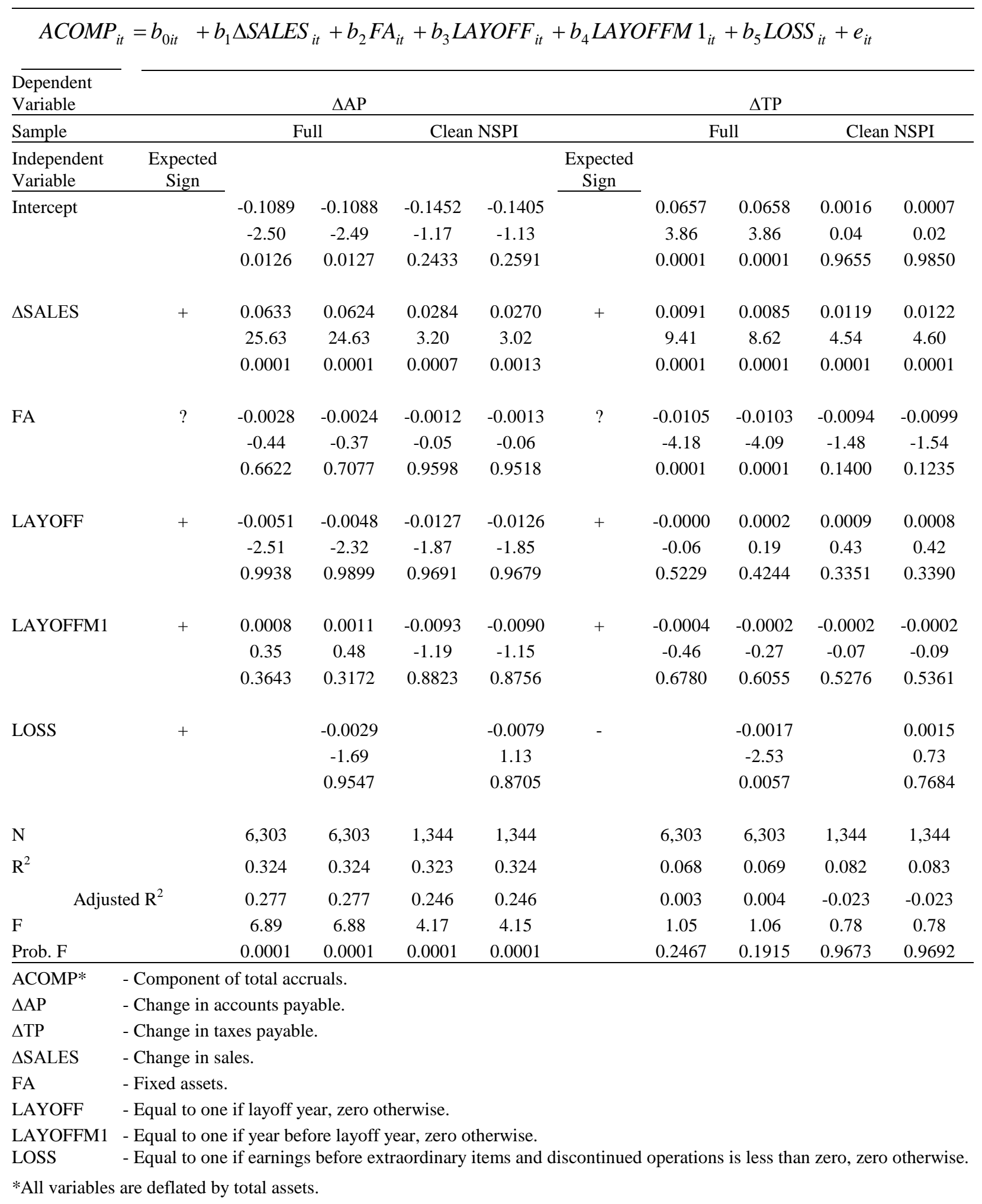


LAYOFF is not significant in the direction predicted in the $\triangle \mathrm{AP}$ model. It is, however, significant in the opposite direction. This drop in accounts payable should not be surprising considering the drop in inventory. To determine the effect of lower inventory levels, we estimated accounts payable as a function inventory level using univariate regression. Results indicate a coefficient of 0.2731 and significance of $p \leq 0.0001$. While we find no manipulation of accruals associated with accounts payable to decrease reported income, we can also conclude that our results in the components measure of accrual models are not driven by accrual of liabilities associated with the layoffs.

The results in the depreciation model are not simple to interpret. While LAYOFF is significant $(p \leq 0.0001)$ using the full sample ${ }^{14}$ that significance disappears when the sample is reduced to exclude firms with special items. It appears that the significant increase in depreciation expense in the event year is reported by firms that report special items. LAYOFF was not significant in the direction predicted in the deferred tax expense model. It was, however, significant in the opposite direction. To discover the extent to which the increased depreciation expense contributed to the decreased deferred tax expense, we estimated deferred tax expense deflated by total assets as a function of deflated depreciation expense. Results indicate a coefficient of -0.0347 and a significance of $p \leq 0.0001$. Thus, we would expect deferred taxes to have the opposite effect in the model as depreciation expense would have. These results using the individual components of accruals indicate a decline in accounts receivable and inventory and an increase in depreciation expense in the event period, supporting conclusions drawn from the estimates derived from the total accruals models.

To better visualize the effect of layoff events on the individual components of accruals, we calculate the residuals for each component of accruals by estimating model (6) and substituting the six individual components of accruals for total accruals. The residuals are plotted in Figure 2. Notice that both the accounts receivable and inventory accruals drop substantially in the layoff year and increase substantially in year +1 . Notice also that the depreciation accrual in the full sample increases in each of the three years $-2,-1$, and 0 , and decreases in each of the three years +1 , +2 , and +3 . These results are expected. Since accounts receivable and inventory accruals are self-reversing in the following year, we would expect to see the decline in year zero followed by an increase in the succeeding year. The depreciation accrual is not self reversing in the short-term; therefore, increases in depreciation can be made in anticipation and have effects that linger longer than current accruals.

[Please insert figure 2 about here]

Our definition of LAYOFF included the arbitrary cutoff of one percent of the total workforce. We tested the sensitivity of our results to this cutoff by repeating estimates of model (5) using other workforce percentages as the cutoff. We used cutoffs of two, three, five, ten and twenty percent. Results are similar to those in Tables 3, 4, and 5. Several of the statistically significant t-statistics related to LAYOFF decrease slightly when the cutoff is increased. Most of these, however, remain significant. Some t-statistics increase. None of our conclusions are changed by the results using higher cutoffs.

We had some difficulty in defining event years for some firms. If announcement of layoffs is made in the first few months of a fiscal year, we don't know if the firm cares more about adjusting the current quarter's earnings or the prior quarter's (prior year's) earnings. Tests reported thus far make the announcement year the event year. To adjust for the potentially confounding effect of announcements in the first three months of a fiscal year, we deleted all firms with significant layoff announcements in the first three months of the fiscal year (reducing the sample to 4,594 firm years) and re-estimated models reported in Tables 3 and 4. In cases where LAYOFF and LAYOFFM1 were significant as predicted in Tables 3 and 4, t-statistics were generally larger when firms with announcements in the first three months were deleted. 
Figure 2 - Panel A:

Discretionary Accounts Receivable Accruals

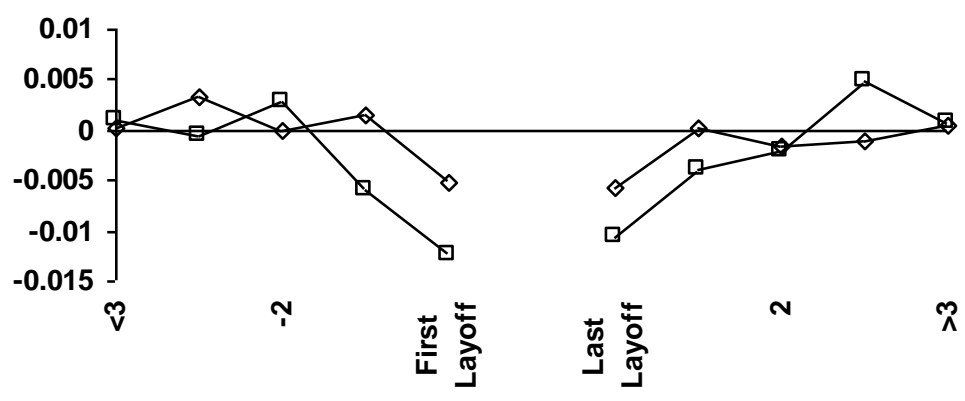

Figure 2 - Panel B:

Discretionary Inventory Accruals

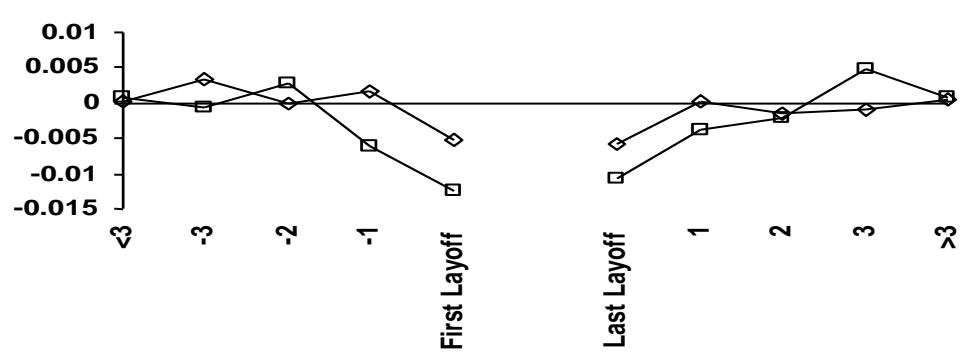

Figure 2 - Panel C:

Discretionary Accounts Payable Accruals

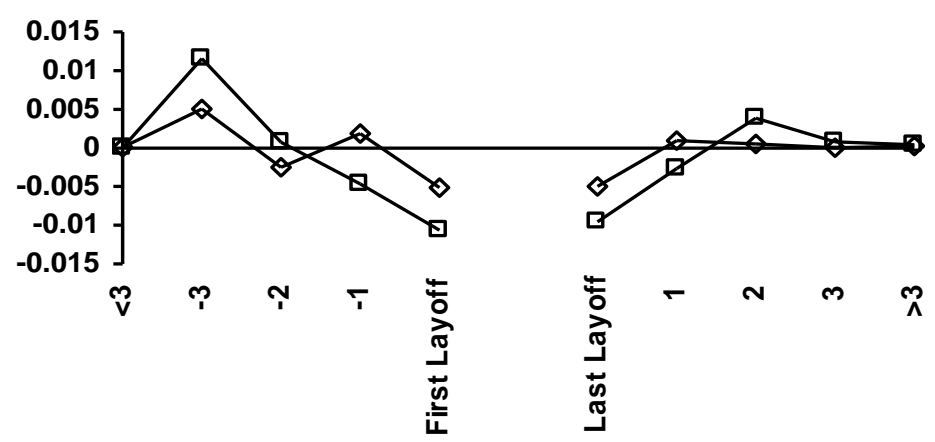


Figure 2 - Panel D:

Discretionary Taxes Payable Accruals

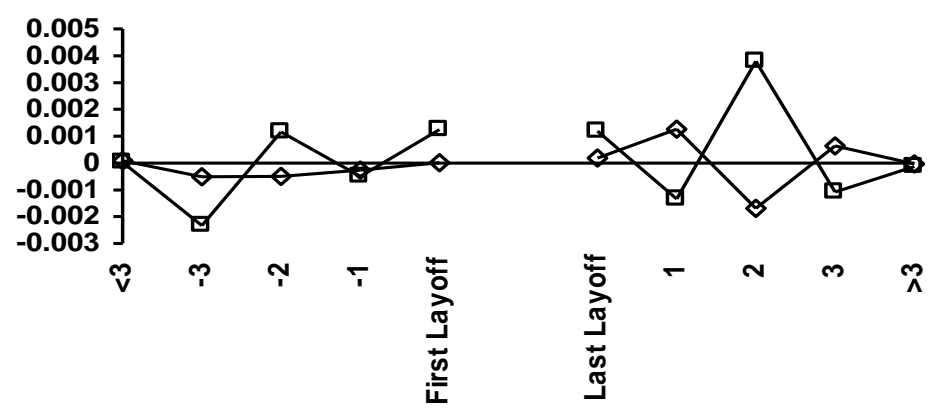

Figure 2 - Panel E:

Discretionary Depreciation Accruals

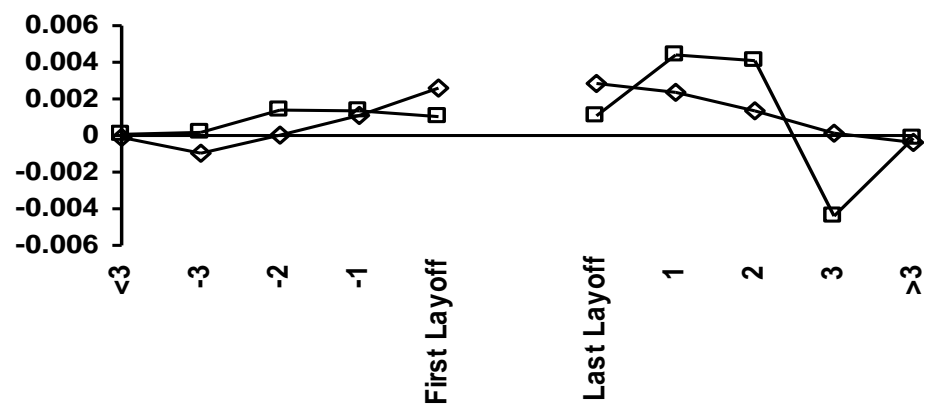

Figure 2 - Panel F:

Discretionary Deferred Tax Accruals

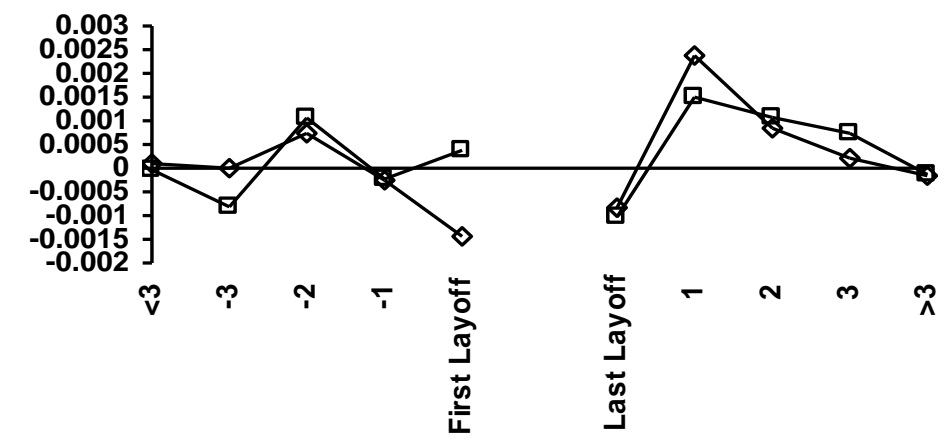

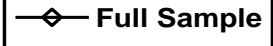

$\square-$ Clean NSPI 


\section{SUMMARY AND CONCLUSIONS}

This study examines the discretionary accrual behavior of firms that announce large layoffs. The findings are consistent with the hypothesis that firms use accruals to decrease reported earnings in periods in which they announce large layoffs. We find that in the announcement year discretionary accruals are made to decrease reported income. In particular, we find a reduction in accounts receivable and inventory and some indication of an increase in depreciation expense. Though our findings are not conclusive, they are suggestive of accrual manipulation surrounding large layoffs. While we cannot attribute a single motivation to this manipulation since it is consistent with several theories of income management, it remains a significant finding that accruals are being managed in periods surrounding large layoffs. Employee groups and other users should be aware that income reports in these periods may be biased downward.

\section{SUGGESTIONS FOR FUTURE RESEARCH}

The findings of this study suggest that further investigation may be need in fully understanding the implications of accounting information released at the same time as large layoffs, and that further investigation of the components of total accruals may be fruitful. While the influence of individual components may become lost in an investigation of total accruals, further study of unexpected changes in each component may reveal more useful information on hoe earnings are actually managed.

\section{REFERENCES}

1. Amir, Eli and Joshua Livnat, Multiperiod Analysis of Adoption Motives: The Case of SFAS No. 106, The Accounting Review, Vol. 71, No. 4, pp. 539-553, 1996.

2. Armstrong-Stassen, Marjorie, Coping with Transition: A Study of Layoff Survivors, Journal of Organizational Behavior, Vol. 15, No.7, pp. 597-621, 1994.

3. Cahan, Steven F, The Effect of Antitrust Investigations on Discretionary Accruals: A Refined Test of the Political Cost Hypothesis, The Accounting Review, Vol. 67, No. 1, pp. 77-95, 1992.

4. Cameron, Kim S., David A. Whetten, and Myung U. Kim, Organizational Dysfunction of Decline, Academy of Management Journal, Vol. 30, No. 1, pp.126-137, 1987.

5. Caudron, Shari, Teach Downsizing Survivors How to Thrive, Personnel Journal, Vol. 75, No. 1, pp. 38-48, 1996.

6. Chen, P., V. Mehrotra, R. Sivakumar, and W. W. Yu, Layoffs, Shareholders' Wealth, and Corporate Performance, Journal of Empirical Finance, Vol. 8, pp.171-199, 2001.

7. Christie, Andrew A., Aggregation of Test Statistics: An Evaluation of the Evidence on Contracting and Size Hypotheses, Journal of Accounting and Economics, Vol. 12, No. 1, pp.15-36, 1990.

8. Dechow, Patricia M., Richard G. Sloan, and Amy P. Sweeny, Detecting Earnings Management, The Accounting Review, Vol. 70, No. 2, pp.193-225, 1995.

9. Fudenberg, Drew, and Jean Tirole, A Theory of Income and Dividend Smoothing Based on Incumbency Rents, Journal of Political Economy, Vol. 103, No.1, pp. 75-93, 1995.

10. Greenberg, Jerald, Organizational Justice: Yesterday, Today, and Tomorrow, Journal of Management, Vol. 16, No. 2, pp. 399-432, 1990.

11. Hall, Steven C., and William W. Stammerjohan, Damage Awards and Earnings Management in the Oil Industry, The Accounting Review, Vol. 72, No. 1, pp. 47-65, 1997.

12. Healy, Paul M, The Effect of Bonus Schemes on Accounting Decisions, Journal of Accounting and Economics, Vol. 7, No. 1, pp. 85-107, 1985.

13. Hribar, Paul, and Daniel W. Collins, Errors in Estimating Accruals: Implications for Empirical Research, Journal of Accounting Research, Vol. 40, No. 1, pp. 105-134, 2002.

14. Jones, Jennifer J., Earnings Management During Import Relief Investigations, Journal of Accounting Research, Vol. 29, No. 2, pp.193-228, 1991.

15. Lambert, Richard A., Smoothing Income as Rational Equilibrium Behavior, The Accounting Review, Vol. 59, No. 4, pp. 604-618, 1984. 
16. Pindyck, Robert S., and Daniel L. Rubinfeld, Econometric Models and Economic Forecasts, McGraw Hill, New York, 1981.

17. Watts, Ross L., and Jerold L. Zimmerman, Positive Accounting Theory: A Ten Year Perspective, The Accounting Review, Vol. 65, No. 1, pp. 131-156, 1990.

18. Wensky, A. H., Turning Crisis Into Opportunity, HR Magazine, Vol. 35, No. 3, pp. 84-88, 1993.

19. Whetten, David A., Organizational Decline: A Neglected Topic in Organizational Science, Academy of Management Review, Vol. 5, No. 4, pp. 577-588, 1980.

20. Whigham-Desir, Marjorie, Strategies for Coping with Workplace Depression, Black Enterprise, Vol. 24, No. 2, pp. 77-82, 1993.

\section{END NOTES}

${ }^{1}$ Christie (1990) and Watts and Zimmerman (1990) review the literature.

${ }^{2}$ See, for example, Fudenberg and Tirole (1995), Lambert (1984), and Healy (1985).

${ }^{3}$ These hypotheses are described by Amir and Livnat (1996), among others.

${ }^{4}$ Greenberg (1990) summarizes the literature.

${ }^{5}$ Armstrong-Stassen (1994) in a study of layoff survivors finds that "how survivors perceive a workforce reduction, particularly in terms of their own job security, is a more important determinant of how they cope than the coping recourses they have available (p.617)."

${ }^{6}$ When this test is repeated without the adjustment to the Jones (1991) model recommended by Dechow et al. (1995), the model F-statistic is slightly higher and t-statistic for LAYOFF is slightly lower. However, these changes are small and would not affect any conclusions drawn from the tabulated results.

${ }^{7}$ We read all entries under the headings of downsizing, layoffs, and unemployment.

${ }^{8}$ A cutoff was needed to eliminate announcements of layoffs affecting a trivial number of employees. One percent is an arbitrary number. Cutoffs of $2 \%, 3 \%, 5 \%, 10 \%$, and $20 \%$ yield similar results.

${ }^{9}$ The requirement that the preceding years have no large layoff announcements is to reduce the possibility that the prior-year effect on accruals is contaminated by prior announcement of large layoffs.

${ }^{10}$ The $\mathrm{R}^{2}$ of forty-one percent is considerably higher than the fourteen percent reported by Hall and Stammerjohan (1997) and the twenty-three percent reported by Jones (1991) and considerably lower than the sixty-four percent reported by Cahan (1992).

${ }^{11}$ Mean (all amounts in millions) of total assets for our sample is $\$ 10,150$. Mean net income is $\$ 237$, resulting in a mean return on assets of 0.023 . The coefficient on LAYOFF of -0.0083 represents a reduction in reported accruals (and thus, income) of $0.83 \%$ of total assets, and a $36.1 \%$ reduction in ROA (-0.0083/0.023). Return on median assets produces similar results.

${ }^{12}$ Hribar and Collins (2002) used absolute values of $\$ 10,000$ for their cutoffs.

${ }^{13}$ To ensure that the significant results for LAYOFF in the accounts receivable model are not driven by our use of the modified Jones model estimation of discretionary accruals, we reestimated the accounts receivable components model with discretionary accruals measured without subtracting the change in accounts receivable from the change in sales in the event years. There is no significant change in results. The results for LAYOFF is slightly weaker in the full sample results and a little stronger in the clean NSPI sample.

${ }^{14}$ There is the possibility that the significant results LAYOFF in the depreciation model are caused by a decline in the scalar in the event years and not by an increase in depreciation. We control for that possibility by including the level of fixed assets as control variable in the model. In addition, we looked at the mean of total fixed assets in event time. The mean of total assets increases in each year. There is almost no increase in assets in the first event year. There is, however, no decrease in fixed assets in the event years. Thus, it does not appear that a decrease in total assets accounts for the significant results for LAYOFF in the depreciation model. 


\section{NOTES}

